\title{
The Current Situation of Coenopopulation of Lepidium subcordatum Botsch. et Vved. (Brassicaceae) in Relict Mountains Kyzylkum (Uzbekistan)
}

\author{
Tashkhanim T. Rakhimova, Nodira K. Rakhimova, Khabubullo F. Shomurodov, \\ Bekhzod A. Adylov*, Vasila K. Sharipova
}

Institute of Botany, Academy of Sciences of the Republic of Uzbekistan, Tashkent, Uzbekistan

Email:*bekhzod_a@mail.ru

How to cite this paper: Rakhimova, T.T., Rakhimova, N.K., Shomurodov, K.F., Adylov, B.A. and Sharipova, V.K. (2018) The Current Situation of Coenopopulation of Lepidium subcordatum Botsch. et Vved. (Brassicaceae) in Relict Mountains Kyzylkum (Uzbekistan). American Journal of Plant Sciences, 9, 2612-2625.

https://doi.org/10.4236/ajps.2018.913190

Received: September 18, 2018 Accepted: December 14, 2018 Published: December 17, 2018

Copyright $\odot 2018$ by authors and Scientific Research Publishing Inc. This work is licensed under the Creative Commons Attribution International License (CC BY 4.0).

http://creativecommons.org/licenses/by/4.0/

\begin{abstract}
Lepidium subcordatum Botsch. et Vved. (Brassicaceae) is a rare endemic species of relict mountains of the Kyzylkum desert. The plant is listed in the "Red Data Book of Uzbekistan". It grows on stony and rocky slopes of relict mountains. The ontogenetic structure of five coenotypical populations of this taxa growing in the Kuldzhuktau and Auminzatau mountains had been revealed. The ontogenesis duration is more than 20 years in natural habitats. All investigated coenopopulations can be assessed as normal and incomplete. The typical spectrum of coenopopulations is centralized with a peak in the middle-generative individuals. The ontogenetic spectrum of the most studied coenopopulations coincides with the characteristic ontogenetic structure that indicates a favorable environmental condition in region for self-maintenance of $L$. subcordatum coenopopulations.
\end{abstract}

\section{Keywords}

Ontogenesis, Ontogenetic Structure, Coenopopulations, Endemic Species, Brassicaceae, Kyzylkum

\section{Introduction}

The genus Lepidium L. is one of the largest genera of the Brassicaceae consisting of 175 species. It is distributed worldwide, primarily in temperate and subtropical regions; the genus is poorly represented in Arctic climates, and in tropical areas it grows in the mountains. Lepidium is characterized by angustiseptate, dehiscent, usually notched fruits; a single pendulous, usually copiously mucila- 
ginous seed in each locule; strongly keeled valves; and tooth-like nectar glands [1].

According to the current data, 49 species grow in Central Asia [2]. In Uzbekistan, there are found only 10 species [3]. Thorough review of the herbarium materials in FRU, TASH, LE and ALTB revealed one more species of this genus-Lepidium cardiophyllum (Pavlov) Al-Shehbaz in the Flora of Uzbekistan [4]. The most species of Lepidium in Uzbekistan have a wide environmental range. They grow on saline and solonetz of deserts, on river valleys, on fine-grained slopes of low mountains and in the rock crevices at the middle mountain belt. Some of them are ruderal species. Eight species ( $L$. aucherii Boiss. L. crassifolium Walldst. et Kitag., L. latifolium L., L. obtusum Basiner, L. perfoliatum L., L. pinnatifidum Ledeb., L. songaricum Schrenk and L. subcordatum Botsch. et Vved.) are found in Kyzylkum desert including its Kazakhstan part. These plants produce a lot of aboveground mass and have a great feeding value. There were attempts to introduce some species of Lepidium into the culture under desert conditions due to their rather soft shoots among numerous rough-stemmed desert shrubs [5].

The present work is devoted to the study of the current population state of rare and endemic representative of this genus-Lepidium subcordatum Botsch. et Vved.

\section{Materials and Methods}

Study area. The field research was carried out in 2015-2018 on the territory of relict mountains in the Kyzylkum (Kuldzhuktau and Auminzatau mountains), in desert plant communities. These mountains constitute isolated hills on the plain area, stretched in the sub-latitudinal direction. They are considered to be the western continuation of mountain systems of Central Asia.

The Kuldzhuktau ridge is $80 \mathrm{~km}$ in length. Its highest point is $789 \mathrm{~m}$ a.s.l. The altitude of the eastern part of the Kuldzhuktau is $685 \mathrm{~m}$; on the western part it is $466 \mathrm{~m}\left(\mathrm{~N} 40.81385^{\circ} \mathrm{E} 063.60541^{\circ}\right)$. The Auminzatau ridge is parallel to Kuldzhuktau and located on $25 \mathrm{~km}$ to the north. Its length is $50 \mathrm{~km}$. The highest point is $694 \mathrm{~m}$ a.s.l., the maximal altitude in the eastern part is $512 \mathrm{~m}$ a.s.l., and $646 \mathrm{~m}$ in the western part $\left(\mathrm{N} 41.15697^{\circ}\right.$ E063.62281 $\left.{ }^{\circ}\right)$. Surroundings of the Kuldzhuktau and Auminzatau mountains are occupied by Kyzylkum sandstones.

The climate of this region is dry continental. The total solar radiation in the region is $130-140 \mathrm{kcal} / \mathrm{cm}^{2}$ per year, and the radiation balance is $45-50 \mathrm{kcal} / \mathrm{cm}^{2}$ per year. The total of temperatures above $10^{\circ} \mathrm{C}$ is $3600^{\circ} \mathrm{C}$. The mean temperature is $10^{\circ} \mathrm{C}$ for January and $26^{\circ} \mathrm{C}-29^{\circ} \mathrm{C}$ for July. The growing period lasts $200-210$ days (240 - 270 days in the southern Turan desert). The precipitation regime is similar to the Mediterranean type. The total precipitation is $100-150 \mathrm{~mm}$ per year. The snow cover in the region is more stable [6]. The water and temperature regimes are characterized by the dryness index $(2.5-6.0)$. The soil cover is formed by the combination of sandy and gray-brown soils that are saline in va- 
rying degrees [7].

Field survey and sampling. During field expeditions, five coenotic populations of Lepidium subcordatum were revealed (Figure 1).

Lepidium subcordatum (klopovnik, lepidium subcordate) is perennial herb, up to $50 \mathrm{~cm}$ tall (Figure 2). The stems are formed from multicipital head. A root crown is covered with scarious remnants petioles of dead leaves. The leaves are numerous, pubescened with thick hairs, large-toothed or pinnatipartite, gradually narrowed into petiole. Racemes attached to flowers are very dense, and attached to fruits lax. The species blooms in late April and May, fruiting in May-June. It grows on stony and rocky slopes of relict mountains, occurs separately or in groups by 3 - 5 individuals.

The concise description of eco-phytocoenotic characteristic of surveyed coenopopulations (CP) is given in the current work (Table 1).

The first coenotic population was studied on the southern spur of the Kuldzhuktau mountain range (with granite outcrops) at an altitude of $462 \mathrm{~m}$ above sea level ( $\mathrm{CP} \mathrm{N} 40.80876^{\circ} \mathrm{E} 063.60431^{\circ}$ ), with coarse-grained soil. It grows among of the sagebrush community. Artemisia diffusa Krasch. ex Poljakov. is a dominant species. The total projective cover of herbage is $14 \%$. This community consists of 34 species, including single species of trees and shrubs, 17 perennials, 15 annuals. The second coenotic population was described on the southwestern part of the Auminzatau (N41.18193 ${ }^{\circ}$ E063.50417 ${ }^{\circ}, \mathrm{h}-589$ ). Salsola arbuscula Pall. and Artemisia diffusa Krasch. ex Poljakov dominate in this plant community. At the survey time the total projective cover of herbage did not exceed $5.0 \%$. The number of species in this community is 17,14 of them are herbaceous

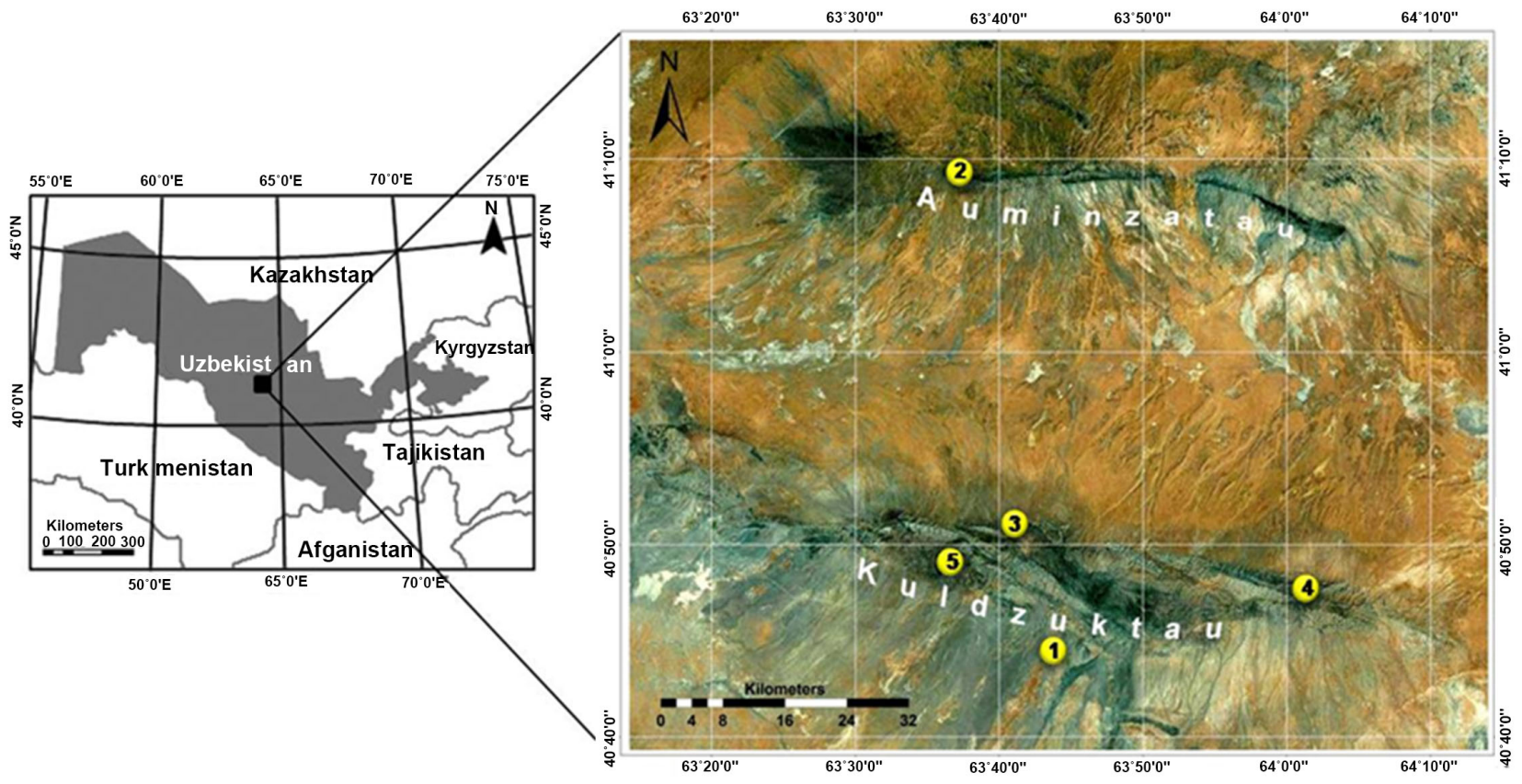

Figure 1. Study area and locations of Lepidium subcordatum coenopopulations in Kuldzhuktau and Auminzatau mountains. 


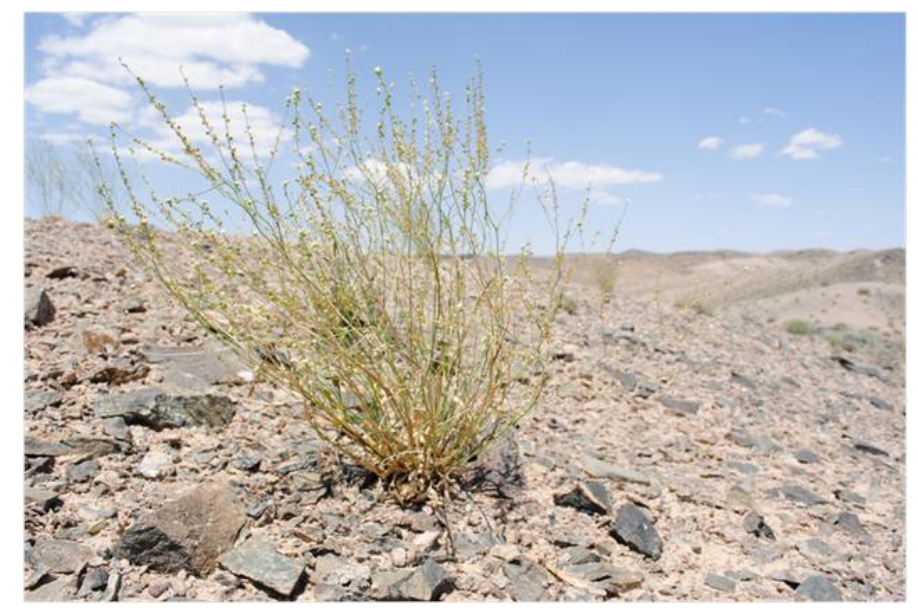

Figure 2. Lepidium subcordatum.

Table 1. Location characteristics of the coenopopulation (CP) of Lepidium subcordatum.

\begin{tabular}{|c|c|c|c|c|c|c|}
\hline № CP & $\begin{array}{l}\text { Geographical location of } \\
\text { coenopopulation }\end{array}$ & $\begin{array}{l}\text { Geographical } \\
\text { coordination }\end{array}$ & Altitude, m & Dominant and Subdominants & $\begin{array}{c}\text { Total projective } \\
\text { cover of herbage, } \%\end{array}$ & $\begin{array}{c}\text { Projective cover } \\
\text { of species, } \%\end{array}$ \\
\hline 1 & $\begin{array}{l}\text { The southern spur of } \\
\text { Kuldzhuktau mountain } \\
\text { (with granite outputs) }\end{array}$ & $\begin{array}{l}\mathrm{N} 40.80876^{\circ} \\
\mathrm{E} 063.60431^{\circ}\end{array}$ & 462 & $\begin{array}{l}\text { Artemisia diffusa, Lepidium } \\
\text { subcordatum, Poa bulbosa }\end{array}$ & 14 & 2 \\
\hline 2 & $\begin{array}{c}\text { The southwestern part of } \\
\text { Auminzatau }\end{array}$ & $\begin{array}{l}\mathrm{N} 41.18193^{\circ} \\
\mathrm{E} 063.50417^{\circ}\end{array}$ & 589 & $\begin{array}{c}\text { Artemisia diffusa, Salsola } \\
\text { arbuscula, Ferula kyzylkumica }\end{array}$ & 5 & + \\
\hline 3 & $\begin{array}{l}\text { The north-western slope } \\
\text { of Kuldzhuktau } \\
\text { (around Shaydaras-well region) }\end{array}$ & $\begin{array}{l}\mathrm{N} 40.84264^{\circ} \\
\mathrm{E} 063.67217^{\circ}\end{array}$ & 681 & $\begin{array}{c}\text { Artemisia diffusa, Salsola } \\
\text { arbuscula, Ammothamnus } \\
\text { lehmanii }\end{array}$ & 6 & + \\
\hline 4 & $\begin{array}{c}\text { The north-eastern slope } \\
\text { of Kuldzhuktau } \\
\text { (Bashguzhumdy-well region) }\end{array}$ & $\begin{array}{l}\mathrm{N} 40.79072^{\circ} \\
\mathrm{E} 064.02746^{\circ}\end{array}$ & 667 & $\begin{array}{c}\text { Artemisia diffusa, Salsola } \\
\text { arbuscula }\end{array}$ & 5 & + \\
\hline 5 & $\begin{array}{l}\text { The eastern slope of Kuldzhuktau } \\
\text { (Sultanbibi-well region) }\end{array}$ & $\begin{array}{l}\mathrm{N} 40.76418^{\circ} \\
\mathrm{E} 063.77235^{\circ}\end{array}$ & 436 & $\begin{array}{l}\text { Artemisia diffusa, Artemisia } \\
\text { scoparia, Scariola orientalis }\end{array}$ & 4 & + \\
\hline
\end{tabular}

plants. Other coenopopulation was investigated on the north-western slope of the Kuldzhuktau (N40.84264 ${ }^{\circ}$ E063.67217 $\left.{ }^{\circ}, \mathrm{h}-681\right)$, in neighborhood of Shaydaras well. The total projective cover of the community with domination of Salsola arbuscula Pall. is not more than $6.0 \%$. Botanical composition of this community amounted up to 21 species.

The fourth coenopopulation allocated on the East Kuldzhuktau (N40.79072 ${ }^{\circ}$ E064.02746, $\mathrm{h}-667)$, in region of Bashguzhumdy well. This plant community dominated by Artemisia diffusa Krasch. ex Poljakov. The total projective cover of herbage included 17 species of vascular plants, that did not exceed 5.0\%. The last coenopopulation described in the central part of Kuldzhuktau mountain (near Sultanbibi well region) (N40.76418 $\left.\mathrm{E} 063.77235^{\circ}, \mathrm{h}-436\right)$. In this area the plant grouping dominates by Artemisia diffusa Krasch. ex Poljakov. The total projective cover of herbage didn't exceed $4.0 \%$. The species composition of plant communities on the rocks were 18 species, the majority of them were annual and perennial herbs. 
Studying the ontogeny of species was performed a conception of discrete description of ontogeny, first proposed by T.A. Rabotnov [8]. Plant nomes are given in the latest verort of S.K. Cherepanova [9]. The life form of plants is given according to the X volume "Conspectus Florae Asiae Mediae» [10]. Coenopopulation structure of the plant was given elaborated by A.A. Uranov [11] [12] and his students [13] [14].

According to abovementioned sources, the plant life cycle is divided into four periods: latent, virginal, generative, senile. The latent age-state (primary dormancy state) represents an embryonic plant enclosed in seed; coenopopulation thus represents by seed bank in the soil. The virginal age-state (pregenerative) is the period from germination to the beginning of generative breeding of individuals. Within a virginal period the plants can be distinguished by the following age-states: seedlings (young growth) ( $p$ ) with mixed feeding (due to seed or cotyledons substances and assimilation of the first leaves); the presence of morphological connection with seed and/or the presence of cotyledons; the presence of embryonic structures as cotyledons, primary (embryonic) roots and shoots. The juvenile $(j)$ age-state has unformed features of mature individuals, leaves with differ shape and location on shoots, other than those mature individuals; a differ type of shoots growth and branching, also the loss of connection with seed, the absence of cotyledons. A characteristic feature of the immature (im) age-state is the onset of branching: the transitional from juvenile to mature plants, in particular the form of the leaves, root system and shoots structure. Virginile $(v)$ plants begin to show the main features for the typical mature individuals, but reproductive organs are still absent.

Generative age-state. The plants are characterized by the development of sexual organs and by the ability to form seed. Within this period the plants distinguished the following age-states: young generative plants $\left(g_{1}\right)$, formation of new parts. Prevailing new growth processes over death of old parts, demonstrated in various forms. The final formation is of mature individuals. Middle-age generative plants $\left(g_{2}\right)$ show a relative equilibrium in the processes of formation and death of structures. They usually show the maximum yearly increase in biomass, the quantity of reproductive organs and maximum seed productivity. Old generative plants $\left(g_{3}\right)$, characterized by prevails of processes of parts death over the formation new ones, the generative activity is diminished, as is the rate of root and shoot formation.

Senile (postgenerative) is age-state, when plants are not able to seed reproduction and doomed to death. The postgenerative plants divided on: subsenile plants (ss) fruit development practically ceases, the death process sharply prevail new growth, the vegetative structure is simplified, frequently the leaves of transitional (immature) type appear once more; senile plants $(s)$ characterized by accumulation of dead parts, and absence of viable buds.

Coenopopulation structure. Coenopopulation structure was investigated by common method [12] [13]. A transects were placed at $10 \mathrm{~m}$ length, they were divided on $1 \mathrm{~m}^{2}$ plots. Each coenopopulation includes from 10 up to 30 plots 
over $1 \mathrm{~m}^{2}$. The ontogenetic structure of coenopopulation was defined as the ratio of individuals different ontogenic states in coenopopulation. An individual had been taken as a unit of account. In characterizing the population structure we based on the submissions of the typical ontogenetic spectrum [15]. Four types of spectra are distinguished by specifics of distribution of ontogenetic groups: sinistral, centralized, dextral and bimodal. The typical spectrum depends on the biological characteristics of species. Coenopopulations were described according A.A. Uranov and O.V. Smirnova [16] classifications and "delta-omega" by L.A. Zhivotovsky [17].

Delta $(\Delta)$ is an index of age population [12], which assesses the age state of coenopopulations at any time, and omega $(\omega)$ is an efficiency of plant in i-ontogenetic state (the "load" value on the environmental energetic resources, expressed as a load' part produced by plants in middle-aged ontogenic state of this population). According to this classification, $\mathrm{CP}$ is young, mature, transition, maturing and old.

Population density. The population density was determined by the quantity of individuals per unit area. The emphasis was put on the average density, i.e. the quantity per unit of whole area, also on ecological density being the quantity per unit of inhabited area that can actually be occupied by population [18].

Reproductive efforts. Reproductive efforts of plants were determined by weight ratio of generative structures to total weight of individual [19]. The assessment of coenopopulations was carried out using organismic and population characteristics [15]. For that, the range of each feature was divided into five classes with the same volume on equable scale; then each class was assigned a score; the lowest score was matched to the lowest parameters. The assessment results are presented as multiaxis diagrams.

\section{Results and Discussion}

Ontogenesis of Lepidium subcordatum. The ontogenesis of L. subcordatum (latent, virginal and initial stages of reproductive state) was described by I.F. Momotov [5] in the collection nursery of the Southwestern Kyzylkum. According to the author, the plant enters in juvenile and immature states in the first and second years of vegetation, and the reproductive state falls on the second and the third years.

Detailed study of ontogenesis $L$. subcordatum under natural conditions was not previously conducted. The ontogenesis of present species has been described during the field studies in the Kyzylkum desert (Figure 3).

The latent state. Lepidium subcordatum seeds are very small size, the seeds length is up to $2 \mathrm{~mm}$, width is $1 \mathrm{~mm}$. Under laboratory conditions, at $23^{\circ} \mathrm{C}$ $25^{\circ} \mathrm{C}$, the first two cotyledonary leaves appear in $7-8$ days, their length up to 0.3 - $0.5 \mathrm{~cm}$, width $0.2 \mathrm{~cm}$. In 10 - 12 days more, the seed germination reached $14 \%$. At this time, the length of hypocotyl reached $1.5-2 \mathrm{~cm}$, and the root of $6-9 \mathrm{~cm}$. The seed germination was $50 \%$ after 20 days of seeding. 


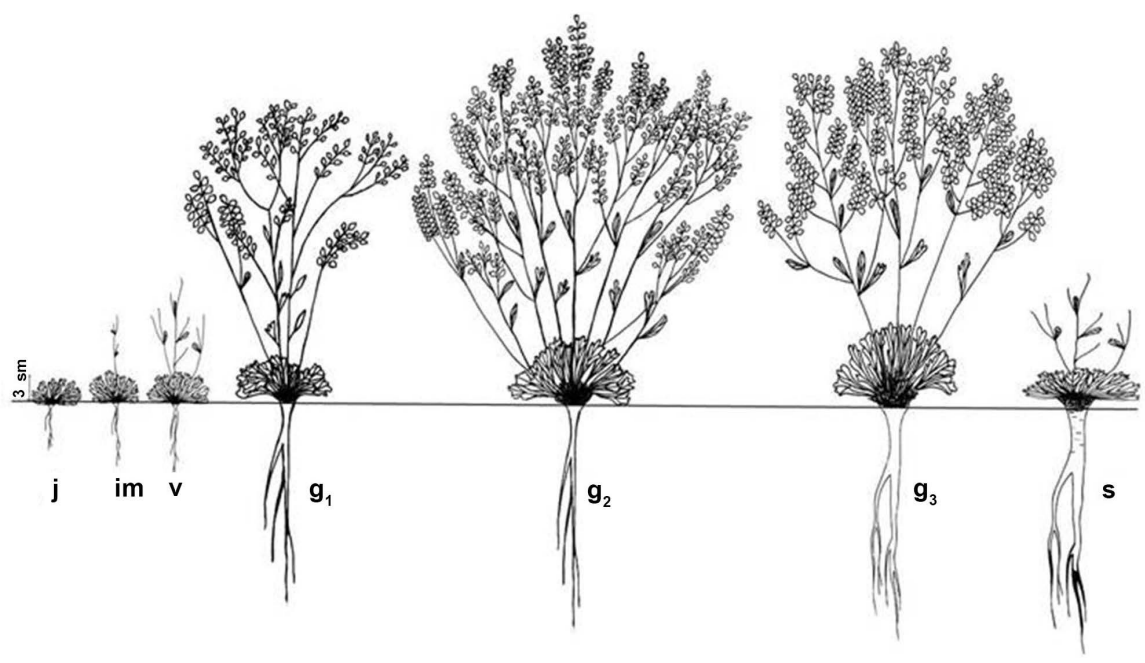

Figure 3. Schematic representation of age states in the ontogeny of Lepidium subcordatum: $j$-juvenile, im-immature, $v$-virginal, $g_{1}$-young generative, $g_{2}$-middle-age generative, $g_{3}$-maturing generative, $s$-senile.

In the virginal state we marked juvenile, immature and virginal state ages.

Juvenile plant. The first dissected leaves with three segments appear in April. In May the plant has a rosette form of 5 - 6 true leaves, i.e. leaves are collected in bunch. The length of leaves with petiole is $3 \mathrm{~cm}$, and without petiole $1.5 \mathrm{~cm}$. The leaves quantity increased to 10 units on the one rosette. The root is thin, vertical, deepened up to $13 \mathrm{~cm}$. The development of lateral roots is observed in $2 \mathrm{~cm}$ from the main root, up to $4 \mathrm{~cm}$ length. In the first year of vegetation the plants stay in the juvenile state of ontogeny in winter (Figure $3(j)$ ).

Immature plant. In the first year of vegetation some individuals develop aerial shoots. The main shoot reached up to $15 \mathrm{~cm}$ at this age, with $1-2$ lateral shoots, $1-2 \mathrm{~cm}$ length. The leaves quantity increased up to 13 on the one rosette (Figure 3(im)).

Virginal plant. At the virginal age state the plant transit on the 2 - 3 year of vegetation. The main shoot reached up to $20 \mathrm{~cm}$ at the end of May. It has $1-3$ lateral shoots, $2-3 \mathrm{~cm}$ length. At this time $1-2$ rosette leaves come to dry. The number of leaves on the one rosette increased to 20 units. Just $5-7$ leaves were withered during July. The root depth is up to $25 \mathrm{~cm}$ (Figure 3(v)). The duration of this state is up to 2 years.

Generative state. This period are represented: young, middle-aged, old generative state. Young generative state $\left(g_{1}\right)$-plant calendar age is 3 - 6 years of vegetation. Plant is $25-40 \mathrm{~cm}$ tall. The number of generative shoots is $2-3$, there are no vegetative shoots. Rosette leaves consist of 11 - 16 leaves. 3 - 4 leaves are green, others are dry. 4 - 5 stem leaves are green. The quantity of fruits in one bunch reaches $30-90$. The branching procedure is III. The root length is $30-35$ $\mathrm{cm}$ (Figure $\left.3\left(\mathrm{~g}_{1}\right)\right)$. The duration of this form lasts for up to 4 years.

Middle-age generative state $\left(g_{2}\right)$ - plant calendar age is 5 - 7 years of vegetation. Plant height is $45-50 \mathrm{~cm}$. The number of generative shoots is up to 20 . The 
number of rosette leaves is up to 30 , all of them are dry. Middle and upper parts of the leaves are green. The branching procedure is III. The quantities of fruits in one bunch reaches are $40-130$. Roots length $40-45 \mathrm{~cm}$, the lateral roots are 30 $35 \mathrm{~cm}$ (Figure $3\left(\mathrm{~g}_{2}\right)$ ). The duration of this state lasts $10-15$ years or more.

Maturing generative state $\left(g_{3}\right)$-generative shoot is $50 \mathrm{~cm}$ tall, their number is about 8 . The plant fruited abundantly at the end of May, 2015. The branching procedure is III. The number of rosette leaves is up to $55,80 \%-90 \%$ of them has dried (Figure $3\left(g_{3}\right)$ ). The duration of this state lasts up to 10 years and more.

Senile period. The number of shoots sharply reduced. There are $2-3$ vegetative branches, length $15-20 \mathrm{~cm}$ (Figure $3(\mathrm{~s})$ ). The number of rosette leaves also decreased. The old individuals could not be found, so the process of complete death remains unclear. There are no registered individuals being on the final stage of the life cycle under natural conditions.

Ontogenetic structure. Ontogenetic structure of coenopopulations of L. subcordatum has not been previously studied. According to the classification A.A. Uranov and O.V. Smirnova [16] studied coenopopulations of L. subcordatum are normal, but are not complete. There are no juveniles individuals in some $\mathrm{CP}$, and no one senile plants were found in investigated coenopopulations. There is no explanation for this fact yet, it's probably due to the biology of this species, or the reason is in successive nature of coenopopulations.

Ontogenetic structure of the most investigated coenopopulations is centralized type with a peak on the middle-generative individuals (CP 1, 3, 4, 5). The exception is CP 2 with sinistral type of ontogenic spectrum (Figure 4).

On the assumption of the biology features of species (only seed reproduction, rapid transition to flower and slowdown development of individuals in middle-age generative state and rapid withering away). A characteristically spectrum of coenopopulations of this species is centralized type with a peak in the middle-generative individuals. Ontogenetic spectrum of the most investigated coenopopulations (CP 1, 3, 4, 5) coincides with the characteristic. This indicates more favorable environmental conditions for self-maintenance of coenopopulations of L. subcordatum.

The lack of undergrowth in CP 1 and CP 3 due to washout of young immature individuals during spring rainfall and overgrazing, and also irregular of seed reproduction. CP 1 grows in gravel soil on the top watershed, here there is soil erosion as a result of hail, whereupon the young immature plants are easily washed off. CP 3 studied surrounding Shaydaras well area. Here the biggest pastures (about 600 head small cattle) within Kuldzhuktau region. They suffer of affects intensive almost year-round grazing.

Consequently, the pasture undergoing a huge load, a regrowth of many plants (including $L$. subcordatum) is trampled, resulting the minimal amount of immature individuals (not more 6\%) in coenopopulations. A prevalence of middle-age individuals is in this coenopopulations (as in CP 4-5) due to gradual longevity increase of individuals in generative period. 


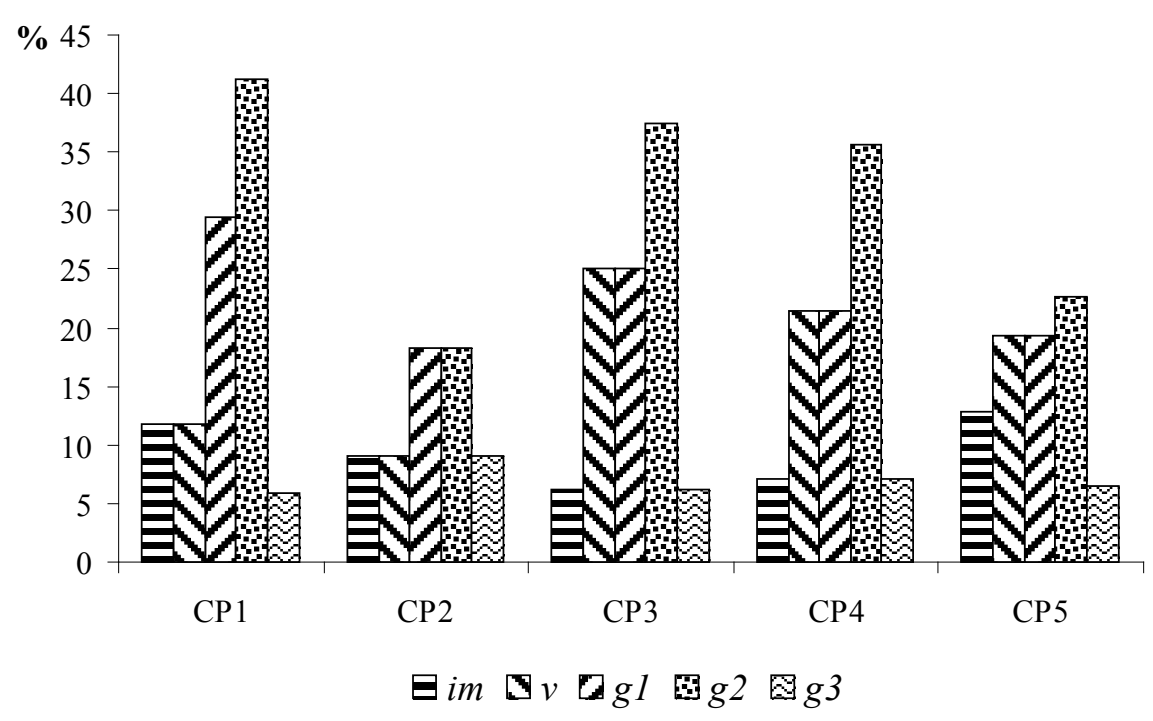

Figure 4. Ontogenetic spectra of coenopopulations of Lepidium subcordatum.

CP 5 grows on the cracks of rocks, in inaccessible areas for grazing. Such relief allowed more equable distribution of ontogenetic groups on the left and central parts of spectrum. The percentage of immature individuals is $12.9 \%$, juvenile, virginal and young generative is $19.4 \%$, middle-generative is $22.6 \%$. The low rates of old generative individuals in all investigated coenopopulations associated with dying off large amounts of individuals during middle-generative state.

CP 2 with sinistral type of ontogenic spectrum. The absolute maximum falls on juvenile individuals (36\%). This variant of spectrum is formed at abundant fruiting. The pastures located in this coenopopulation (south-western part of Auminzatau is territory far from settlements) in early spring with food abundance in the piedmont plains are not used. They are usually used in late spring. This fact promotes the formation of a significant amount of fruits in generative plants and at the same time, a better rooting of young individuals. But, of course, not whole undergrowth is survived, most of it falls down. It is demonstrated in the spectrum, the number of immature individuals in $\mathrm{CP}$ is more than three times less than the juvenile.

The age assessment $(\Delta$-delta) and effectiveness ( $\omega$-omega) of coenopopulations of $L$. subcordatum had been shown, CP2 $(\Delta=0.2 ; \omega=0.4)$ and CP5 $(\Delta=$ $0.2 ; \omega=0.5)$ are young; $\mathrm{CP} 1(\Delta=0.3 ; \omega=0.7), \mathrm{CP} 3(\Delta=0.3 ; \omega=0.7)$ and $\mathrm{CP} 4$ $(\Delta=0.3 ; \omega=0.6)$ are maturing (Table 2$)$.

The density of individuals in investigated coenopopulations varies on the average from 1.1 to 3.1 individual per $\mathrm{m}^{2}$, ecological density is within 1.8 to 5.1 individual per $\mathrm{m}^{2}$.

Assessment of coenotic populations state of Lepidium subcordatum. To assess the coenopopulations state as organismic parameters we selected: reproductive efforts of individuals (R/E); biomass of individuals; plant height; leaf length; the number of generative shoots. As a population signs were taken the density of 
Table 2. Demographic characteristics of coenopopulations of Lepidium subcordatum.

\begin{tabular}{cccccc}
\hline № $\mathrm{CP}$ & $\begin{array}{c}\text { Density of } \\
\text { individuals, } \mathrm{m}^{2}(\mathrm{pc})\end{array}$ & $\begin{array}{c}\text { Ecological } \\
\text { density of individuals, } \mathrm{m}^{2}(\mathrm{pc})\end{array}$ & $\Delta$ & $\omega$ & CP type \\
\hline 1 & 1.7 & 3.4 & 0.3 & 0.7 & maturing \\
2 & 1.1 & 1.8 & 0.2 & 0.4 & young \\
3 & 1.6 & 3.2 & 0.3 & 0.7 & maturing \\
4 & 1.4 & 2.3 & 0.3 & 0.6 & maturing \\
5 & 3.1 & 5.1 & 0.2 & 0.5 & young \\
\hline
\end{tabular}

individuals per $1 \mathrm{~m}^{2}$; ecological density of individuals per $1 \mathrm{~m}^{2}$; the proportion of individuals young fraction $(j-v)$; the proportion of individuals generative fraction $\left(g_{1}-g_{2}\right)$; the proportion of old generative individuals $\left(g_{3}\right)$.

To assess the coenopopulations state the range of each feature was divided into five classes with equal volume on uniform scale; then each class was assigned a score (Table 3). The evaluation results are presented in the form of multiaxis diagrams (Figure 5).

Assessment of coenopopulations state by organismic parameters has shown that maximum reproductive effort (5 scores) occurs on the north-east slope of Kuldzhuktau, around Bashguzhumda well. A high values of (R/E) in CP 4, probably depends on its phytocoenotic situation. Here, the total projective of herbage cover does not exceed $5 \%$, i.e. virtually no competition. This fact contributes to more effective shoot formation of Lepidium subcordatum. Decreasing of $\mathrm{R} / \mathrm{E}$ of individuals can be observed on the large stony and rocks areas, with low moisture and nutrients content in the root zone of substrate (CP 1, 2, 3, 5).

The maximum biomass of individuals in studied species is marked in CP 1 (5 scores) occurs to the southern ridge spurs of Kuldzhuktau mountains (neighboring to granite deposits) with coarse-grained soil. The present coenopopulation has been studied as a part of successional communities. On this territory there was granite mining until recently. Apparently, Lepidium subcordatum recently implemented in this community develops normally due to the lack of competitive species and forms a great level of phytomass. In all remaining coenotic populations, the biomass of species assessed one score.

The highest plants were fixed on the rocks of central part of Kuldzhuktau, here the plants community is virtually absent (CP 5). The vast majority of individuals grows under the rocks shade. As a rule, under these conditions the considerable energy is required for shoot formation, to get more sunlight. In the rest coenopopulations the plant height does not exceed $42 \mathrm{~cm}$, and they assessed one (CP 1, 2 and 3) and three (CP 4) scores.

The largest leaves are fixed in CP 1 and 5 (5 scores). The leaves length reaches $2.5 \mathrm{~cm}$ in these CP.

Its high value is indicated in CP 2 (4 scores), less is in CP 3 (3 scores) and the lowest is in $\mathrm{CP} 4$ (1 scores). The leaves enlargement due to successive community state (CP 1) and lack of sunlight (CP 5). 
Table 3. Ranking point of Lepidium subcordatum signs value.

\begin{tabular}{|c|c|c|c|c|c|c|}
\hline \multirow{2}{*}{ № } & \multirow{2}{*}{ Signs } & \multicolumn{5}{|c|}{ Points } \\
\hline & & I & II & III & IV & $\mathrm{V}$ \\
\hline 1. & Reproductive efforts, \% & $35.7-39.6$ & $39.7-43.6$ & $43.7-47.6$ & $47.7-51.6$ & $51.7-55.6$ \\
\hline 2. & Biomass of individuals, $\mathrm{g}$ & $10.6-24.5$ & $24.6-38.5$ & $38.6-52.5$ & $52.6-66.5$ & $66.6-80.6$ \\
\hline 3. & Plant height, $\mathrm{cm}$ & $31.0-34.4$ & $34.5-37.9$ & $38.0-41.4$ & $41.5-44.9$ & $45.0-48.3$ \\
\hline 4. & Leaf length, $\mathrm{cm}$ & $1.6-1.7$ & $1.7-1.9$ & $1.9-2.1$ & $2.1-2.3$ & $2.3-2.5$ \\
\hline 5. & Number of generative shoots & $2.6-4.6$ & $4.6-6.7$ & $6.7-8.8$ & $8.8-10.9$ & $10.9-13.0$ \\
\hline 6. & Density of individuals, per $\mathrm{m}^{2}$ & $1.1-1.4$ & $1.5-1.8$ & $1.9-2.2$ & $2.3-2.6$ & $2.7-3.1$ \\
\hline 7. & $\begin{array}{l}\text { Ecological density of } \\
\text { individuals, per } 1 \mathrm{~m}^{2}\end{array}$ & $1.8-2.4$ & $2.4-3.1$ & $3.1-3.7$ & $3.7-4.4$ & $4.4-5.1$ \\
\hline 8. & Proportion $j-v, \%$ & $23.6-29.7$ & $29.8-35.9$ & $36.0-42.1$ & $42.2-48.3$ & $48.4-54.6$ \\
\hline 9. & Proportion $g_{1}-g_{2}, \%$ & $36.4-43.2$ & $43.3-50.1$ & $50.2-57.0$ & $57.1-63.9$ & $64.0-70.6$ \\
\hline 10. & Proportion $g_{3}, \%$ & $5.9-6.5$ & $6.5-7.1$ & $7.1-7.8$ & $7.8-8.4$ & $8.4-9.1$ \\
\hline
\end{tabular}

A maximum ( 5 scores) and a big number of generative shoots (4 scores) are noted in CP 4 and CP 1. More generative shoots are formed in successive communities and in places with less phytocenotic pressure. Overgrazing, shadow and large stone slopes limit the number of generative shoots.

The assessment of coenopopulations by population parameters has shown, the highest proportion of young plants faction ( 5 scores) occurs to the black marble in the south-western part of Auminzatau (CP 2) and on the rocks of the central part of Kuldzhuktau (CP 5). According to our research, the number of young faction in coenopopulations doesn't correlate with the number of generative shoots and reproductive effort of individuals. This is clearly demonstrated on figure. The proportion of young faction of investigated species mostly depends of coenopopulation location. Than coenopopulations are more inaccessible to cattle, the more young individuals. Below values (1, 2 points) fall on coenopopulations located along watercourses or pasturelands (CP 1, 3 and 4).

A maximum value (5 scores) of middle-generative plants has noted in $\mathrm{CP} 1$, a high value (4 points) is in CP 3 and 4 . A minimum value is fixed on the big-stony slopes of Auminzatau (CP 2), and on the rocks of the central part of Kuldzhuktau (CP 5). The old generative individuals dominate in CP 2 (5 scores). In the rest coenopopulations they are assessed by one or two scores. The highest density of individuals (5 points) is established in CP 5.

Thus, none of investigated coenopopulations the maximum values of organismic and population features do not coincide. CP 5 can be considered as the most optimal ecological and phytocenotic condition for this species. Three of five population features and two of organismic features have been assessed by 5 scores.

\section{Conclusions}

Thus, the big life cycle of Lepidium subcordatum consists of several age-states under Kyzylkum desert conditions. The total life duration of this species under 

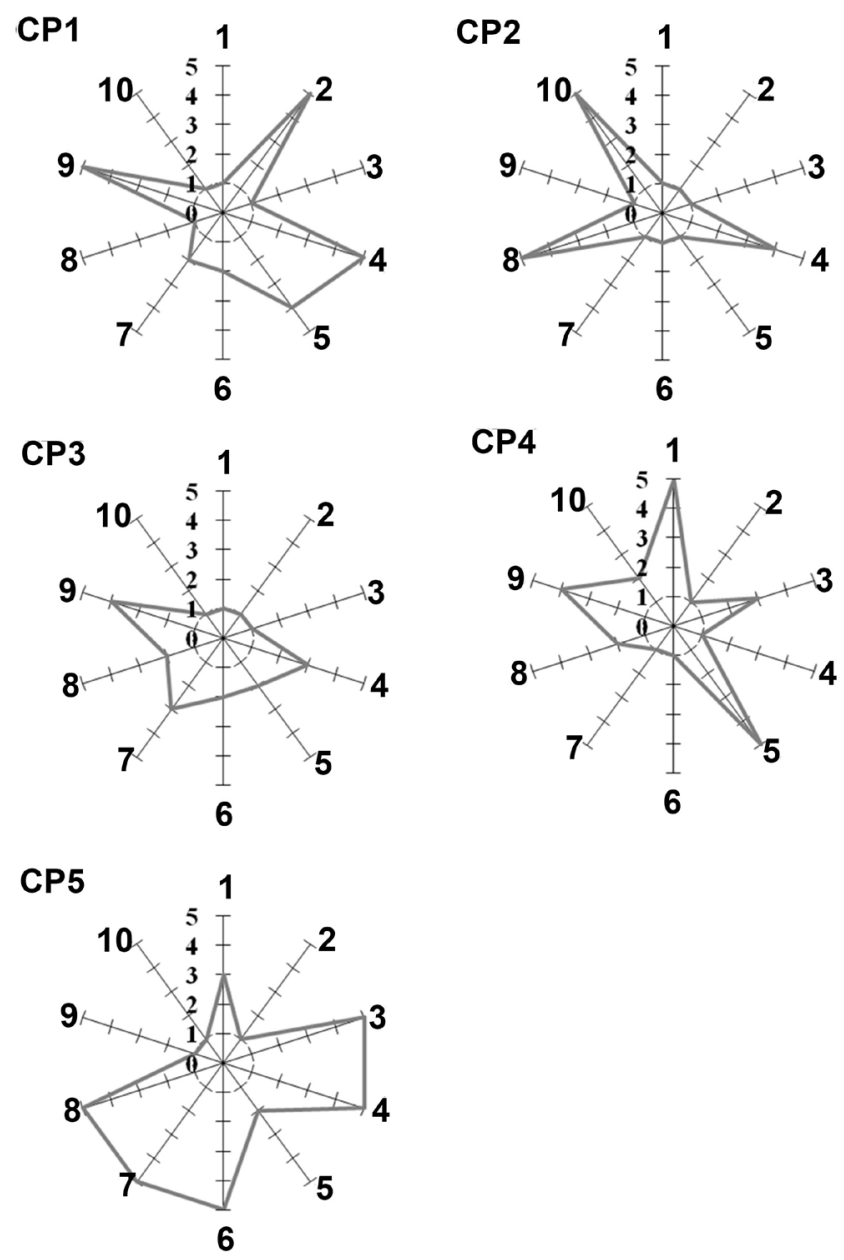

Figure 5. Assessment of coenopopulation state of Lepidium subcordatum (in scores): organismic parameters: 1-reproductive efforts of individuals (R/E), 2-biomass of individuals, 3-plant height, 4-leaf length, 5-number of generative shoots; population parameters: 6 -density of individuals, $\mathrm{m}^{2}, 7$-ecological density of individuals per $\mathrm{m}^{2}, 8$-proportion of individuals in young fraction $(j-v), 9-$ proportion of individuals in middle-aging fraction $\left(g_{1}-g_{2}\right), 10$-proportion of individuals in aging fraction $\left(g_{3}\right)$.

Aral desert condition is more than 20 years. It should be understood that different individuals may extend the intended age states at different speeds. The influence of anthropogenic factors leads to any disorder in nature.

The longest ontogenesis of individuals falls on the middle-generative state. In this regard, a characteristic ontogenetic spectrum of coenopopulations of $L$. subcordatum centered with a peak in mature generative individuals.

Coenopopulations of studied species are normal, and not complete. Ontogenetic structure of species is associated with eco-coenotic growing conditions and seed production. In most cases (except CP 2) the real and basic ontogenic spectra of $L$. subcordatum coincide with the characteristic one. It indicates more favorable environmental conditions of the area for self-maintenance of coenopo- 
pulations L. subcordatum.

Assessment of coenopopulations state by complex of parameters has revealed that the most coenopopulations of studied species is in pessimal state. Under optimum growth conditions the values of organismic and population parameters are high, but not always close to maximum.

In general, by set of organismic and population parameters, the vast majority of studied coenopopulations $L$. subcordatum is assessed as pessimal and needed protection. Considering the research area as one of the important botanical territories of Uzbekistan and to protect $L$. subcordatum populations, also the number of other rare species, such as Astragalus sentralis, Ferula kyzylkumica, Stipa aktauensis, Lagochilus vvedenskyi, Tulipa lehmanniana, and so on, their status assessed as regression, the Kuldzhuktau mountains are recommended for taking in system of protected natural areas of Republic.

\section{Acknowledgements}

The current work is done under the project FA-A7-T005 "Assessment of coenopopulations state of rare and endangered species occur to the Kyzylkum low mountains due to desertification" with the financial support of the State Committee of Science and Technology of the Republic of Uzbekistan.

\section{Conflicts of Interest}

The authors declare no conflicts of interest regarding the publication of this paper.

\section{References}

[1] Klaus, M., Holger, B. and John, B. (2001) Chloroplast DNA Phylogeny and Biogeography of Lepidium (Brassicaceae). American Journal of Botany, 88, 2051-2063. https://doi.org/10.2307/3558431

[2] Khassanov, F.O. (2015) Conspectus Florae Asiae Mediae. Vol. 11, Fan, Tashkent, 154-156.

[3] Bochancev, V.P. and Vvedensky, A.I. (1955) Family Cruciferae. Flora of Uzbekistan, 3, 195-200.

[4] German, D.A., Lazkov, G.A., Tojibaev, K.S. and Neveraev, U.A. (2013) New Data on the Species Composition and Distribution of Cruciferae from Kyrgyzstan and Uzbekistan. Botanical Journal, 9, 1166-1175.

[5] Momotov, I.F., Padunina, V.M. and Berkovich, B.V. (1989) Ontogenesis and Forage Quality of Herbaceous Perennials, Suitable for the Desert Pastures Phytomelioration. Problems of Desert Development, 4, 46-52.

[6] Rachkovskaya, E.I. (2003) Natural Features of Kazakhstan and Central Asia/Botanical Geography of Kazakhstan and Central Asia within the Desert Area. Institute of Biology, Academy of Sciences Russia, St. Petersburg, 13-17.

[7] Shomurodov, H.F., Saribayeva, S. and Akhmedov, A. (2015) Distribution Pattern and Modern Status of Rare Plant Species on the Ustyurt Plateau in Uzbekistan. Arid Ecosystems, 5, 261-267.

[8] Rabotnov, T.A. (1950) The Study of Populations Composition for the Phytocoenol- 
ogy Purposes. Botany Problems, 1, 465-483.

[9] Czerepanov, S.K. (1995) Vascular Plants of Russia and Adjacent States (the Former USSR). Cambridge University Press, Cambridge, 516.

[10] Vvedenskiy, A.I. The determinant of plants in Central Asia. Vol. I-X, Fan, Tashkent.

[11] Uranov, A.A. (1967) Ontogenesis and Age Structure. Ontogenesis and Age Structure of Flowering Plants. Nauka, Moscow.

[12] Uranov, A.A. (1975) Age Spectrum of Phytocoenopopulations as a Time Function and Energetic Wave Processes. Biological Sciences, 2, 7-34.

[13] Smirnova, O.V. (1976) Plant Coenopopulations (Development and Interrelations). Nauka, Moscow, 55-60.

[14] Zaugolnova, L.B. (1988) Plant Coenopopulations (Essays Population Biology). Nauka, Moscow, 98-104.

[15] Zaugolnova, L.B. (1994) The Structure of the Populations of Seed Plants and the Problems of Monitoring. Resume of Dissertation of Doctor of Biological Sciences.

[16] Uranov, A.A. and Smirnova, O.V. (1969) Classification and Basic Features of Perennial Plant Populations. Bulletin Biology Section, 2, 119-134.

[17] Zhivotovsky, L.A. (2001) Ontogenetic State, Effective Density and Classification of Populations. Russian Journal of Ecology, 32,1-5.

[18] Yu, O. (1986) Ecological Density of Individuals. Ecology, 2, 230-376.

[19] Markov, M.V. and Pleschinskaya, E.N. (1987) Reproductive Effort in Plants. Journal of General Biology, 1, 77-82. 